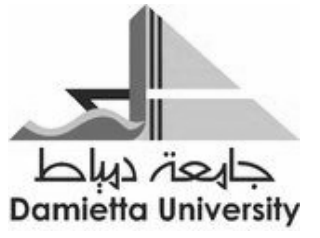

Damietta University

Faculty of Arts

Leon Uris's Exodus and The Haj: a False Presentation of History.

By

Shaimaa Mohamed Hassanin 


\section{Leon Uris's Exodus and The Haj: A False Presentation of History.}

The establishment of a cultural Jewish supremacy in Palestine has been a major concern for many Zionist writers. Therefore, Jewish writers make their presence deeply felt by crafting a unique Jewish character in their literary works. Some of these Jewish writers exhibit their imagination and energy to write about the rebirth of Zionist entity and bring forward what lies deep in them like dilemmas and confusions. Thus, Cultural Zionism needs a true passion and talented writers, who can express their attachment to the land. Leon Uris, with his historical fiction in Exodus and The Haj, generally gives a new meaning to Cultural Zionism and Jewish writings.

In his Middle Eastern novels, Uris points out the mythological, biblical, fictional and historical ideas that capture the region. Also, he narrates his stories as unfolding history and adopts the strategy of interweaving historical stories to create credible narration that can satisfy his passion towards the newly-born state. So, the content of Jewish history in Uris's novels is a part of folklore, biblical stories, factual events and characters. Through such stories, Uris creates what is called historical fiction. However, the greatest difficulty for any historical novelist lies in finding a balance between historical and imaginary events, fictional and factual characters, without one drowning out the other.

Historical fiction does not only narrate past events, but it also shows the consequences of these events in the present and the future. So, historical novels aim at reconstructing a past way of life that arouses special feelings in its readers. If a novelist takes historical fiction as historical documents, he thus shows responsibility and obligation towards his readers. He is committed to portray historical facts as they are, but he is free to 
create the political and social motivations of the characters that perform these facts. In a historical novel, the novelist has the freedom to describe his characters as he wishes, but he does not have the freedom to make certain historical figures behave in a way opposite to what is really known about their manners from reliable historical documents. As Hawthorn claims, the novelist can tell stories about fictional characters like love affairs:

He [the novelist] can arrange the private affairs of his imaginary characters, like their loves and their conflicts, in various ways, but the great events, like the sequence of battles, the victories and defeats are prescribed by history.

One of the greatest benefits of historical fiction lies in presenting history through the eyes of several characters using many techniques of narration. Thus, reading a historical novel can be equal to reading a historical document if it is objective and not subjective. Also, a historical novel plays an important role in representing neglected and forgotten history through making people re-live their past. Therefore, a historical novel is not something which transfers place, time and history, but it also clarifies typical historical conflicts and structures. Through a novel, certain things may be clarified, such as, consequence of events, conflicts and sources of historical events.

Writing a historical novel about a specific period can be a challenge to the writer, because it requires a balance of facts with a need of creating a compelling story that draws the readers' attention. Usually, the events of a historical novel fall within the factentertainment area which will get criticized for being too didactic or too entertaining. Hence, the ceiling of creativity will get higher if a historical novelist chooses to write about something that is particularly controversial. 
On this basis, Uris uses Exodus and The Haj as an indication of historical documents that include many fictional and factual events. Such events show Uris's preoccupation with the Arab-Israeli conflict and his attempt to connect historical events and their engagements with Israel's political, economic and cultural growth. Through historical events, Uris portrays many Jewish and Arab characters and appears to be reluctant in emphasizing his characterization, an attitude which may create a confusing atmosphere. Through the main events of the novels, Uris does not include reliable sources or evidence to give his readers a chance to judge without any pressure.

It is confusing to know that Uris wrote Exodus and The Haj as a response to a prior request from Jewish-American public relations. Edward Gottleib, who was employed by the Israeli government after its emancipation in 1948, commissioned Uris to go to Israel and write a novel about it. Also, he funded Uris's journey to Palestine and secured him all the necessary needs. Exodus (1958) was the outcome of this journey, aiming at satisfying people who were questioning the right of the Jews to have their own state at the expense of others. Writing for one side of the conflict constitutes a major flaw in Uris's literary career, because it deprives him of objectivity. According to Khalidi:

The book [Exodus] was commissioned by a renowned public relations professional, a man who was in fact considered by many to be the founder of public relations in the United States, a fellow by the name of Edward Gottleib, who desired to improve Israel's image, and who chose Uris to write the novel after his successful first novel on World War II, and secured the funding which paid for Uris' research and trip to Israel. (3)

On the other hand, The Haj was published in 1984 when strong political voices questioned the legitimacy of Israel's policies in Palestine. These voices sympathized with 
Palestinians and condemned the Israeli massacres committed against Arabs like, Sabra and Shatila in Lebanon in 1982. Moreover, these voices constituted a source of danger for Jews inside and outside Israel. As a result, many scholars and politicians tried to distract them by asking Uris to write a second novel about the Middle East, showing "the barbarism" of Arabs, as Silver declares:

The Haj is a part of our story of the making and unmaking of Exodus because Uris's inability to negotiate a distinction between legitimate critical analysis of a subject and sheer delegitimaization of the topic is not merely a moral failure. Uris was not insensitive about the specific facts of Palestinians suffering, but he remained trapped by a story line that conceptualized Zionist righteousness as an all or nothing commodity. (192)

In Exodus, the use of symbolic titles is evident as Uris refers to the biblical return of Jews from Diasporas to the Promised Land. This sacred land is necessary for Jewish culture and identity and constitutes a major element in their lives. Uris asserts that only in Palestine, Jews can be safe. Again, the title of The Haj is symbolically significant; according to Uris, The Haj is a title where every corrupted Arab leader can hide behind. Arabs in The Haj represent an obsolete race that must be eliminated, like Ishmael's family, to give the new race a chance to build its civilization.

The difference in perspective manifest in the two novels is also found in the names given to the protagonists. In Exodus, an example is given of the Hebrewization of names as Jews arrive in the Promised Land, thus highlighting the cultural transformation central to the Zionist propaganda. In The Haj, there is more emphasis on Arab names, like Ishmael, Hagar and Ibrahim, which reveals the message of the novels. Uris's chief protagonists are 
Ari Ben Canaan and Gideon Asch; their Hebrew names evoke the strength of Jewish people inside and outside Israel.

In Exodus, Ari Ben-Canaan, a Jewish Sabra with no typical Jewish features, serves as the main example of assimilated ideals. Due to his position in Mossad Aliyah Bet, he helps many Jews immigrate to the Promised Land. Though he is full of sorrow because of the murder of his beloved by Arabs, he carries on his struggle for his country. Ari is portrayed as very civilized in appearance, behavior and culture. He plays a major role in transforming the world's view of on Jews from anti-Semitism to a more positive image. In addition, Ari represents the modern philosophy of assimilation through his secularized vision of Judaism. Though it is clear that he is a Jewish-Israeli, Ari is a non-religious and secular Jew, who is not complying with any religious traditions. He is not dressed in a way that signifies his Jewish culture, such as: Kippah or head-covering; his words are even nonreligious. In this respect, Uris dedicates his efforts to show Ari as a superior human being representing Jewish people, who are strong, resourceful and determined. In the first appearance of Ari, Uris describes him as a handsome man full of sadness:

A brief flame glowed over the face of the man who was called Ari. He was large and husky, in complete contrast to the small Ben Ami. His face was handsome but there was a set hardness in his eyes. He was Ari Ben Canaan and he was the crack agent of the Mossad Aliyah Bet-the illegal organization. (Exodus 11 )

From the outside, Ari is thought to be incurious and tardy, but from the inside he is an intimate person who does not conceal his emotions. Through the novel, he watches many of his friends killed at the hands of Arabs. Ari's character constitutes a prototype of a modern Jew, a man of action, rather than a droopy person. Featured as a vigorous and 
foxy character, he is intended to emphasize that Jews are capable of defending themselves and "their land". Like most Jews in the novel, he transforms his dramatic experience to enthusiasm to rebuild his life and provide a safe home for other generations. In general, he represents the idea of the "new Jew" who can build his country and defend it against any external threat.

Ari's father, Barak Ben-Canaan, tells a story of how he walks to Palestine with his brother, Akiva, searching for freedom and peace. When they reach the land of Palestine, they find it full of deserts and swamps. They plant eucalyptus trees, which can soak up the swampy water, to encourage Jews immigrate to Palestine and build kibbutzim. By the help of other immigrants, Barak manages to create a perfect Jewish community, which is envied by surrounding Arabs. After many years, Barak succeeds in his endeavor and becomes very satisfied with his deeds. His story forms a significant stage in the history of Jewish pioneers in Palestine. Through their life journey, the core message behind the journey of the Rabinskies is that, Jews can achieve their dreams through patience and persistence:

We are walking to the Promised Land. It was the magic password. "Are there Jews here?" "There is a Jewish family in the next village." Never once were they refused hospitality. Two years went by. The brothers pressed on doggedly, stopping only when exhaustion overcame them or they had to work for food. (Exodus 223)

Uris continues his description of Jews as unconquerable heroes through his representation of Jewish women, who can bravely defend the newly-born state. For example, Jordana, Ari's fiery younger sister and leader in the Palmach (Haganah elite unit), joins the Israeli army, following her mother and fiancé, David Ben Ami. She is portrayed as a beautiful young woman, defending her "home" from "hostile Arabs". After the death of 
David Ben Ami at the hand of Arabs, Jordana carries on her struggle against them, keeping her sorrow within her heart for the sake of Israel. In several scenes in Exodus, Jordana seems to have no humanity and no feminine look. The woman-warrior inside her refuses other women's softness. For her, there is no room for such softness in the life of a soldier, considering herself a soldier first and a woman second. Though described as a beautiful and desirable woman, she still misses the opportunity of being a female. She resembles the first generation in the 'Holy land' that must be prepared all the time to confront different dangers. Though her character is a flat one, does not change through the course of the novel, her qualities are praised for being occupied with the interests of her newly-born country:

If Jordana Ben Canaan had tears for her David, no one ever saw them. She disappeared with her grief into the ruins of Abu Yesha. She sat neither moving nor eating nor drinking for four days and four nights. She returned to Gan Dafna. As Ari had done with his sweetheart, Jordana never mentioned David's name again. (Exodus 544-5)

Like other Jews in the novel, Jewish children are portrayed as young heroes who come to establish a state. One of these children is Karen Hansen Clement, a German refugee, who illegally immigrates to Palestine. She is a melodramatic character whose life is miserable due to leaving her family behind in Germany. Though full of vitality and vigor, she ends up murdered at the hands of extremist Arabs. Furthermore, Dov landau, a polish teenager who survives the Holocaust represents the persistence of Jews of living under harsh circumstances. He ends up in detention camps in Cyprus and then moves to Palestine on board of the Exodus. Soon, he joins the Irgun and later becomes a major in 
the army of Israel. After the death of Karen, his beloved, he devotes himself to the service of Israel:

Karen is dead ... Karen is dead . . ."'If I could only have died for her," Jordana cried. Kitty struggled to her feet."Lie down, dear . . . please, lie down," Sutherland said. "No," Kitty said, "no . . ." She fought clear of Sutherland. "I must see Dov. I must go to him. (Exodus 596)

Before WWII, Nazis took power in Germany and committed many persecutions against Jewish families. As Jews living in Germany and Poland, Karen and Dov suffer severely under Nazi rule. Hence, this puts into perspective that the only thing keeping Holocaust survivors alive is immigration to Palestine, the Holy Land, where they find salvation. Karen and Dov's characters are doomed to show the world that Jews are peaceloving and forgiving people. Due to losing almost everything and everyone in their lives, Karen and Dov live in a great sorrow, hoping to restore their happiness in the "Promised land. Their different manners show Jewish confused reactions to the Holocaust; however, they expect to live freely in their homeland.

Furthermore, Dov represents the idea of the new Jew, who is willing to die with dignity rather than to live with disappointment. In one of the scenes in Exodus, Dov is pushed up against a wall, which represents two thousand years of persecution and humiliation in the Holocaust. All Jews, like Dov, decide to fight back, protect themselves and 'restore' their land. Of course, Uris tries to tickle his readers' emotions through portraying Dov as a victimized person who later becomes a hero, and thus, he is worthy of all their support and admiration.

Karen is Dov's counterpart is filled with hope and tenderness, though her horrible experience in Germany. Her sadness shortly disappears through helping others, and Dov's 
sadness is healed through his participation in the Irgun. Their different characters represent the diverse Jewish reactions towards the Holocaust. However, they both seek a resort to freely and safely. In addition to her extraordinary kindness, Karen becomes a positive link to Christian audiences through her relationship with Kitty, The American nurse. As Karen is a very likeable person, who happens to be Jewish, her character can easily deliver Uris's message that Jews are tolerant people.

Each character in the storyline has a special task: to clearly demonstrate the evils of anti-Semitism and to display the value of life and the need of tolerance towards differences. When Kitty, the American nurse, first meets Jews in Palestine, she can't provide a specific explanation for her prejudice, because her anti-Semitic feelings are clearly based on presuppositions and anti-Jewish stereotypes in European culture. Kitty's character is a typical American one and can easily be identified. Therefore, when she honestly shows her negative attitude towards Jews, many readers who feel the same way begin to relax and not feel guilty about their anti-Semitic feelings towards Jews. Kitty as an American character makes an understandable bond between American readers and Jewish characters. This bond makes a pivotal change in the attitude of American readers towards Israel. Throughout Exodus, Kitty slowly transforms from an anti-Semitic person to a more tolerant one, who learns to accept other races. Also, she learns to stand in the way of every evil that helps spread evil among different races. Kitty's reaction and change transform the readers' collective mind from rejecting Jews to accepting them along with their policies in the Middle East.

In The Haj, Uris carries out his depiction of Jewish characters' heroism, though they have been limited in number as compared to those of Exodus. The main Jewish 
character, Gideon Asch, is portrayed as a man who carries the torch of civilization and knowledge to other races. He is a Jewish spy working for the British Intelligence in Arab lands. Uris does not portray him as a Zionist invader, but as a Sabra who knows the entire region by heart, because he handles many operations in the Arab region under the auspices of the Irgun. Through his friendship with Haj Ibrahim, the muktar of Tabah, he manages to teach him some matters about leadership and contribution to the land. Despite his perfection and idealism, he fails to convince Arabs to get rid of "their superstitions", but he manages to create a perfect kibbutz, Shemesh, that is envied by Arabs in the village of Tabah. In his first appearance, Gideon Asch perfectly expresses himself and gains the admiration of everyone:

'I am Gideon Asch,' the man said in perfect Arabic. 'We have purchased several thousand dunams of land over the road from the Effendi Kabir. We hope to be able to make a farm out of it. I take it you are the muktar?' 'I am the muktar,' Ibrahim said icily as everyone behind him inched in. Ibrahim was extremely quick in sizing up a man's courage. (The Haj 24)

Although the friendship relationship between Haj Ibrahim and Gideon Asch may seem strange and reprehensible at first, Uris wants to provide an opportunity for Arabs to learn from Jews and to participate in building a new civilization in Palestine. Uris tries to provoke the feelings of Arabs by convincing them that only Arabs benefit from such a relation, not Jews. Also, he stresses on the character of Ibrahim, which radically changes as a result of his friendship with Gideon. To sum up, Uris show Jews as saints and ideal persons, while Arabs are presented as children who should learn from Jews how to build a civilized state. 
Featured as a legendary image of "the new Jew", Gideon emerges as a Jewish pioneer on the land of Palestine or a "Shomer" who represents an idealized image of Jewish population in Palestine. As a Jewish spy, who is fully aware of Arab traditions and customs, Gideon tries to impose his Jewish culture to serve a Jewish purpose of controlling Palestine and Palestinians. Gideon represents a charismatic modern figure for all Jews inside and outside Palestine. Through his mythic hero, Uris tries to give his Zionist hero full rights to be assimilated to American image, because Israel and America represent similar ideas of modern man. Thus, Uris creates a hero who can reflect the main features of modern Jews inside Palestine.

The other Jewish characters in The Haj are flat ones and appear in one or two scenes; nevertheless, they have a profound influence on the main characters of the novel. The muktar of Shemesh, who appears to be a woman called Ruth, confuses Haj Ibrahim because of her ability to rule a whole village, like men. In Arab culture, where Haj Ibrahim belongs, women are not allowed to take high positions in the society. So, Uris wants to confirm this idea by showing the ability of Jewish women to run a society. Of course, the mute little Jewish girl, Hannah who carries a little toy, reminds Nada of her lost childhood. Though represented as a flat character, Hannah appears in a time when Nada starts to question the validity of Arab customs of eliminating women from the society. The third character is a Russian whore, Ursula, who completely changes Haj Ibrahim by giving him advice about how to live according to his own beliefs, not depending on others. Ironically, Uris gives a whore all the credits to be an advisor, only because of her Jewish background. In one of her conversions with Haj Ibrahim, he expresses his confusion between new ideas brought by Jews and his own that are implanted in his mind: 
But in the end, I must make all decisions according to Sunna, according to tradition. To live by tradition, one cannot gain too much knowledge for himself. Knowledge clashes with tradition. I have followed the Koran by surah and verse. To do that you must shut out much inquiry. Forgive me, Ursula, I am rambling.' 'Please go on.' 'It is to say I have learned something last night. A friend has been trying to tell me for years to open my mind, my soul (The Haj 192)

The role of Jewish leadership and decision-making hold a great dimension of Exodus and The Haj that is particularly revealing of the propagandistic intention of the novels. All the major Jewish characters are presented as exceptional people that deserve a magical land. Therefore, Jewish characters are important, because they represent an entire race. In this respect, Uris portrays their Jewishness as a special human condition. Ari Ben Canaan and Gideon Asch are clearly superior beings, because they merely represent Jewish people. Jews are, collectively, as strong, resourceful and determined as Ari and Gideon. This positive image is highlighted by the portrayal of other ethnic groupings in the novels. The British, for example, are seen divided and presented as degraded products of imperialism. Also, Arabs are seen as a decadent race and products of a backward civilization.

After 1948, the fictional depiction of Arab-Israeli encounter has been presented from the view point of a first person Jewish narrator, who inevitably urges readers with sugar-coated emotions to accept his views. Exodus and The Haj are oriented by a singular point of view, reflecting a one-sided story. Both novels are narrated through intertwined interior dialogues in which both worlds, Jewish and Arab, are vaguely counterpointed. 
Although they are different from each other, Exodus and The Haj represent a panorama of the relationship between Arabs and Jews in modern Jewish fiction.

The only Arab fictional character in Exodus is Taha, the young Muktar of Abu Yesha, who becomes a friend to Ari Ben Canaan. Taha remains a friend of Ari and Jews, even when pressed by his folks to fight against his neighboring Jews. However, he breaks off his friendship with Ari when the latter refuses to allow him to marry his sister, Jordana. Yet, he helps Ari when he gets injured during a Palmach operation against Arabs by giving him a place to stay. At his house in the village of Abu Yesha, Taha asks Kitty, the American nurse, to come and cure Ari's wounds. After Ari's recovery, Taha manages to smuggle him secretly to Gan Dafna, a nearby kibbutz. As a result, Arab extremists murder Taha and curve the David star on his body. Yet, his dreams of alliance between Arabs and Jews are buried with him. Uris describes Taha's confusing status when he leaves his boyhood friend Ari:

He [Taha] was told that he was an Arab and a Moslem and he had to choose his side. How could he turn on Ari and Barak Ben Canaan? Yet, how could he still the voices around him? He was a brother of Ari. Or was he? This was the tormenting question. From childhood his father had groomed him to lead his village. He knew the Jews had built the great cities and the roads and the schools and they had redeemed the land and they were the enlightened ones (Exodus 363)

Portrayed as a devoted friend, Taha refuses to fight against his close friend Ari and other Jewish neighbors; as a result, he pays his life for this faithfulness. The death of Taha at the hands of Arabs, according to Uris, allows readers to hold a connection between Nazis and Arabs, who are able to kill a member of their own tribe. As Uris claims, Arabs kill 
Taha because their life is based on prejudice. According to many Jewish critics, Taha represents a cross-current symbol to all Arabs traditions of hatred and rejection of diversity. His death represents a tuff moment for all those who long for peace and value life, and it increases sympathy for all Jews and their peaceful endeavors. The readers' grief at Taha's death at the hands of Nazi-Arabs allows understanding the connections between bigotry and terrorism. By the death of Taha, Uris refers to the Jewish horrible experience in the Holocaust.

In The Haj, Uris represents a much strident attitude towards Arabs than that depicted in Exodus. This time, he uses Arabs as the main characters of the novel and focuses on their manners, concentrating on "their dark sides". Though he claims to follow historical and social facts in dealing with Arab history and culture, he does not give any material proof. According to Terry, Uris collects the story of his novels from Arab men living in Palestine, without mentioning their names or positions:

His "sources included a PLO man and 'some of the leading Arabists in the world,' with whose help, [as he says,] 'I really felt that I was able to solve some of the riddles of the Arab mind' although 'it was a helluva lot of work. Many of the events in The Haj are a matter of history and public record. Many of the scenes were created around historical incidents and used as a backdrop for the purpose of fiction. (54)

Through The Haj, Uris uses Ishmael, Haj Ibrahim's youngest son, to criticize his own culture, folks and religion. Ishmael is a young man full of enthusiasm to innovate his society, but he is confronted with the immobility of his Arab culture. He symbolizes a new generation of modern Arabs, who should work with other races to achieve his dreams. So, Uris exploits him as a narrator to show Arabs' dissatisfaction with their culture and their 
desire to change it. In this way, Uris makes Ishmael condemn himself and his people in a kind of self-criticism. As a result of his confusion between Arab and Jewish traditions and his inability to live according to Arab culture, Ishmael goes insane:

Kaif,... It is a word of profound significance to us [Arabs]. It means do nothing, say nothing, think nothing. We deceive ourselves by saying that kaif is the perfect form of patience, but in truth kaif is a philosophy of deliberate idleness, of being half-awake without leaving the world of private fantasy. We go into kaif, a state of semiconsciousness, to alleviate the reality of our suffering. We are men locked in boxes inside our own minds. (The Haj 388)

Viewing with disdain the traditional dogma of Arabs as reflected in their culture, Uris points out that Arabs' beliefs constitute a source of danger not only to Jews, but also to the inhabitants of Tabah. As a result of rejecting his Arab customs, Ishmael isolates himself from an environment which provokes hatred and misery. Ishmael's attitude toward his people is shared by many Arab characters in The Haj. Denouncing Arab traditions as destructive ideologies, Uris demonstrates that the only available salvation for Arabs is to abandon these traditions and become a part of the Jewish state. Apparently, Uris tries to impose his own version of the Arab community in Palestine to give a false idea that can help Jews enhance their international position.

The other Arab characters are depicted as aggressive, revengeful and vicious. They are filled with hatred and grudge towards themselves and others. For example, Haj Ibrahim is a feudal figure, who brutally collects money from peasants. Like all Arabs, he hates Jews and considers them the main movers of every evil. He is married to Hager and Ramiza, whom he treats like puppets. His wives, according to Uris, are "slaves" that follow his orders 
without questioning. Like all Arabs, as Uris claims, he lives in the dark ages, refusing to enjoy modern civilization brought by Jews to enhance Arab lives and lands. He considers his land a part of his soul; that's why he believes that new Jewish technology cannot change the land's infrastructure. Though Ibrahim constantly betrays his folks to satisfy his Jewish friends, he is not allowed to be assimilated into the civilized people of Israel.

Through Ibrahim, Uris uses a racial language which turns his treatment of the relationship between Arabs and Jews into a moral issue.

To confirm his theory of Arabs in The Haj, Uris cunningly reverses facts about Arab culture and society. He summarizes the main characteristics of an Arab as ignorant, villain and illiterate. So, it becomes an easy task for him to create an Arab stereotype that can be easily identified. Also, he identifies the inability of Arabs to learn from modern civilization and culture. For example, when Ishmael wants to enroll in a school, his father denies his request, "Your brother Kammal knows how to read and write. Therefore it is not necessary for you. You will tend the goat flock by your next birthday and the rest of your life is already predestined." (The Haj 12) Uris asserts the inability of Arabs to seek knowledge, though in fact seeking knowledge is a must for every Muslim. Muslims have a proverb that confirms the importance of learning, "Seek knowledge from cradle to grave."

The portrait cannot be complete without describing Arab women in humiliating scenes in The Haj. They are represented as "oppressed slaves" that are captured by their culture, religion and men. In Uris's novels, Arab women are voiceless, featureless and mindless creatures who are doomed to be invisible. In his depiction of Arab women, Uris bases his narrative source on Pre-Islamic era, where pagan traditions conflicted with Islamic ones. By doing so, he exploits the ignorance of western readers about Arab culture 
and takes the advantage of giving them false information. For example, in Pre-Islamic Arabia, giving birth to girls was an insult and disgrace to the whole family, and baby-girls were buried alive to protect their fathers' honor. In The Haj, Uris claims that newly-born girls are considered a disgrace to their families, while male babies are given all the family's credit and full rights. Ishmael shows his father's sorrow when his first born babies were girls, and people called him "father of daughters":

Unfortunately, my parents' first two were girls and this was a small disaster. Everyone, particularly the women at the village well, whispered behind his back that he was Abu Banat, A Father of Daughters, a most terrible insult. (The Haj 15-16)

Though her name evokes purity, Nada's actions evoke rebellion against her society, culture and religion. Due to her hatred to Arab culture, she tries to do unacceptable behaviors to punish her backward society before her family. When Nada becomes a refugee, she starts to question herself about her culture and religion. She sympathizes with the fate of Arab women whose spirits, according to Uris, are crushed by Islamic rituals. Nada herself rejects Islam and Arab culture entirely from childhood, because as she claims, Islam fails to keep her dignity. Having seen what her culture does to its people, Nada exhibits an unusual independence when she leaves Tabah. Sooner, she starts a sexual affair with an employee in the United Nations. Through this secret relation, she tries to control a male-dominated society. Like her brother, Ishmael, Nada must pay for violating Islamic taboos. When she tells her father about her sins, he kills her in cold blood to preserve his honor. Through the character of Nada, Uris shows his vision of Arab women, who have experienced discrimination and subjected to many restrictions inside the Arab society. Some of these discriminations are based on religious and cultural beliefs that stem 
from traditions and customs. According to Uris, Nada is essentially a story of a beaten woman living among a male-dominated society.

In the novels' binary structure, good Jews versus evil Arabs, a model of ethnocentric views of Arabs is established. For example, a symbol of Arab resistance such as Haj Amin El- Husseini, the grand mufti of Jerusalem and the Palestinian hero, is dehumanized in Exodus and The Haj. He appears as a Nazi agent and a criminal, who escaped from a fifteen-year sentence of imprisonment in Palestine. Haj Amin, according to Uris, is "a thief" who steels religious funds and adopts violence by planning massacres against Jews. The Grand Mufti of Jerusalem wears a white cloak, holds a white cane, and his blond hair is so light it is almost white, making him appear as a white devil. Uris dehumanizes a historical figure by making him a gangster and a villain schemer looking for his own benefits.

In The Haj, Haj Amin's distorted image is given more details, as Uris explains how he uses his position to control Arab lands and gain more money from Arab leaders. He is a feudal man who unfairly collects money from peasants. Everything he does is wrong, according to Uris, because he hates Jews and does not cooperate with them in building their modern civilization. Such a combination of characteristics creates a hasty character that urges readers to blame Haj Amin for every act he does:

Using the pulpit and the power and position of his title as Mufti, Haj Amin al Heusseini moved through the decade of the 1920s and spread his tentacles into every corner of Palestine. He was a landowner of enormous properties, which were sharecropped in a feudal tradition. The Mufti's domain was a destitute, illiterate fiefdom of desperate serfs who were easily aroused and manipulated into religious frenzy inside the mosque. (The Haj 62) 
While condemning the Mufti of Jerusalem for advocating his country's interests against Zionists, Uris portrays David Ben Gurion, the first prime minster of Israel, as a wise leader and a Jew seeking freedom and independence for his folks and country. Unlike Haj Amin El-Husseini, Ben Gurion is portrayed as a Zionist pioneer, holding the responsibility for establishing the political and social standards of Israel. In the meantime, Ben Gurion accuses Arabs of being the main reason of war; as a result, it is a must for every Jew to build his own state with his bare hands to feel the joy of "restoring the land" from barbarians:

The Arabs have begged for this war,' Ben-Gurion said. 'But we have too many other priorities to engage in endless quarrels with them. We must win the war and come out of it with a viable state. There are so many things a Jewish state must accomplish, for we and our moral standards must be the light of mankind. (Exodus 220)

The storyline of Uris's novels is not balanced with positive and negative types of characters, and they do not present the true history of the Middle East. The object of Exodus and The Haj is to embrace the goals of cultural Zionism and to reduce Arabs' perception of the lands of Palestine. Though Taha and his Palestinian Arab family, in addition to Ari and his family, are likeable and friendly, the Arab version of this time in history is not really appreciated. Also, the novels portray a few British characters and their relation with Jewish ones, but all the events focus more on the intelligence and cunning of the Jews rather than the gullibility of the British or Arabs. Hence, Jews are the key word in both Exodus and The Haj and all the other character are to serve the Jewish cause.

Familiarity with the novels' philosophy and main characters help the readers understand and relate to the main idea and the purpose of Exodus and The Haj. Thus, the novelist should have represented balanced examples of different characters to strengthen the message of his novels. The heroes, Ari the Sabra, Kitty the Christian American, the British General Sutherland, and the Holocaust survivors Karen and Dov, Gideon Asch the Sabra and Ishmael the Arab who rejects his culture, are ideal characters, with high-quality traits and universal qualities. Their attractive and sophisticated looks represent Israel's 
commitment towards America. Through their bond, the reader can identify their experiences and their assimilation with other races.

According to the Zionist theory brought by Uris, Arabs ought to be grateful for the coming of Jews to Palestine, because they introduce progress and advancement to the Middle East. As a result, Uris draws a portrait of Jewish characters in Exodus and The Haj, showing their holy traits and sophisticated manners in building "the state". On the other hand, he always associates Arabs with barbarism, narrow-mindedness and savagery. For him, good Arabs are those who cooperate with Jews and give a hand in building a new civilization. So, Uris changes their opinion of Arabs according to their acceptance of Jews. Such a manipulating theory creates a biased atmosphere and a paradoxical point of view. However, Uris loses much of his credibility when he declares, "I set out to tell a story of Israel. I am definitely biased. I am definitely pro-Jewish."(qtd. in Roth, 138)

Since the key Zionist narratives are concerned with self-identity, collective history, and the Zionists' relationship with Arabs, Uris finds it easy to emphasis the traditionallyconstructed historical and social narratives by giving Arabs weak characters and Jews stronger ones. According to Uris, the most striking contrast to the collective devotion and astonishing courage of Jews is with Arabs. In spite of their greater numbers, the culture and characters of Arabs allow them to be clearly inferior and decadent. Ari and Gideon, who are Sabras born in Palestine and understand the Arab character, know that they are no match to courageous Jews. Their assessment of the Arab character as indiscipline figures affects the collective consciousness of the readers.

Depending on Uris's Zionist notion in Exodus and The Haj, the main aspects of Arab characters can be summarized in four points. First, he focuses on the external appearance of an Arab without showing his internal personality, like his description of Haj Amin, 
"Bockmann told the Mufti to shave off his beard and wear the clothing he had brought, the white dress that Moslem women wore to prayer on Friday morning." (The Haj 109) Second, he tries to highlight "eastern diseases", such as: forced marriage, beating of women, laziness and sexual lust. Also, he shows Arabs as a race seeking sexual lust by demonstrating the story of Hani, an Arab villager from Tabah, who tries to rape "a faithful Jewish woman" in Shemesh kibbutz after failing to steal her money:

Before she could summon help he seized her and flung her to the earth and in panic beat her badly about the head. Seeing her on the ground and hurt, with her legs open, Hani was overcome with lust. He tore her clothing off and attempted to rape her." (The Haj 63)

Third, Uris explains that Arabs' hatred for Jews is embedded in their culture and ancient traditions. In Exodus, Ari explains to Taha that Arabs hate each other for many years, because they stick to old values and obsolete traditions. On the other hand, Jews are carriers of civilization who hold no hate to any other race, "We [Jews] have brought you things that your own people [Arabs] would not give you in a thousand years. Your father knew this and he was big enough to admit that no one hates or exploits an Arab worse than another Arab." (Exodus 344) Fourth, Uris puts Jews in a constant and sharp competition with Arabs to show the latter's inability to keep the fertility of the land. Eventually, this allows many historical and social falsifications to emerge.

In any dispute between Arabs and Jews, Uris does not miss a chance to expose "Arabs' wicked manners". His interpretation of the Massacre of Deir Yassin as a legal Jewish self-defense shows his binary attitude towards Arabs. Uris claims that the Zionist gangs were defending themselves against "hostile Arabs", "They did not know that a large contingent of Jihad Militia was in Deir Yassin at the time. When they attacked, resistance 
was fierce. The soft target became hard as fighting intensified."( The Haj 211) Jacque de Reyniér, a famous historian explains the related conditions of Deir Yassin Massacre and exposes the false claims of Uris. According to Reyniér, Palestinian refugees were killed in their way to find a refuge and were brutally murdered by Zionist war machines after they got expelled from "their lands and homes" in Palestine; he adds:

The refugee numbers game exploded. In the beginning of the war it was established that a half-million Arabs had fled their homes. Their numbers had been inflated to over a million and were still growing. An accurate census became impossible as Arab administrators in the UNRWA turned a blind eye to the abuses. (15)

The contrast between the Jewish ethnic stereotyping portrayed in Exodus and the portrayal of Arab characters in The Haj shows Uris's subjective attitude towards Arabs. In The Haj, there is no discussion of strategy or tactics used in the Arabs' war against Jews, but random strategies which reflects, according to Uris, Arabs narrow mindedness. On the other hand, Jews simply find themselves in difficult situations and try to survive but their strategies are based on organized plans. In The Haj, there is no visible leader and his existence can only be intuited. Thus, Arabs' plans and strategies are unexplained and unreal. In The Haj, Uris expresses a lack of confidence in Arab leadership and, in this way, it can be understood as the social continuation of Exodus. Therefore, what is missing in Exodus, Arab characters portrayal, is focused upon in The Haj.

Uris claims that Arabs are a backward race, and that they do not have the ability to cope up with modern concepts because, according to him, Islam teaches its followers submission and ignorance. For him, Islam is incapable of understanding the social forces that motivate the modern world. Yet, Uris ignores mentioning that Islam is not an Arab 
religion, and that Arabs are not the only Muslims around the world. It is true that Islam originated in Arab lands, but Prophet Muhammad (Peace be upon him) was sent to all humanity until the Judgment Day, as the Holy Qur'an states, "And we have sent you (O Muhammad) but as a mercy for the 'Alamin (mankind, jinn and all that exists)." (Translation by Muhammed Taqi-Din Al-Hilali, The Holy Qur'an, Al-anbiaa': 107) However, Uris demonstrates his opinion of Islam as the main motivator of backwardness and stagnation: Islam teaches its followers not to think for themselves but to live by the decisions of others ... and when we examine exactly what the submission to God's will means ... we see that it is a form of mental sterilization, for it tells man not to aspire or hope but to accept. (qtd. in Fischel 12)

Uris's derogatory description of Islam in Exodus and The Haj shows his intention of showing it as the main reason of every disaster in the Arab world. He represents every Muslim as a naturally-born killer, following the doctrines of an impractical religion. On this basis, Uris prepares his readers' minds to see how religion can affect people and culture by giving them negative aspects about Islam. Of course, he takes this opportunity to hold a comparison between Arabs and Islam on one side, Jews and Judaism on the other side.

In Exodus, Uris concentrates much on Judaism and gives short and separated images of Islam. Yet, he describes prophet Mohamed (Peace be upon him) as the main figure of Islam, who put its "basic laws". Also, he mentions that Judaism was descended before Islam, so the latter is no more than a cloning of Judaism with slight changes. According to him, many rabbis are holy men in Islam, but he does not give any proof to support his claims. Through these chains of historical and religious falsifications, Uris intends to prove the disqualification of Islam to be a divinely-inspired religion. To him, Islam is no more than a man-made philosophy, which teaches its followers to hate non-Muslims: 
In all Moslem lands, all citizens other than Moslems became scorned as infidels. In their own way the Arabs had grudging respect for the Jews, and in their own way granted them a reasonable amount of tolerance. Arab massacres of Jews were never the calculated genocide of Europe, but rather the flaring of a sudden spark of violence. (Exodus 260)

Uris pursues his distorted image of Islam in The Haj, but in a wider range. He even devotes a whole chapter to insult Islam, Muslims and Prophet Mohamed. Furthermore, historical figures such as: Saladin and many Islamic heroes are portrayed as mercenaries and war criminals. Prophet Mohamed emerges as 'a colonizer', who led an Arab army to invade Palestine and kill many Christians. Also, Qur'an is described as a book filled with violence and inhumane actions towards non-Muslims. According to Uris, Islam means "submission to God's will" without thinking:

Islam means 'the submission to God's will.' A Moslem is 'one who submits.' Mohammed was an impoverished and illiterate camel driver from Mecca who married a rich widow. This allowed him to pursue his calling. He received his mission by going up to Mount Arafat for forty days and receiving instructions from Allah Himself. The Koran, a collection of Mohammed's sermons, was not written until many years after his death by people who had listened to him and were divinely inspired to remember everything he said. Since he was the final prophet, all other religions were therefore obsolete. (The Haj 166)

Uris's attempt to profane Islam and Prophet Mohamed is a part and parcel of his endeavor to degrade Arab culture and civilization. As a result, he mocks every sacred event in Islamic life such as: the legendary journey of Prophet Mohamed from Mecca to Al-Aqsa mosque, the noctumal joumey and ascension, by describing Al-Buraq as a mythic Greek figure 
that had a woman's face and a peacock tail. Such a deceptive description of the great legendary journey of Prophet Mohamed is abused by Uris to undermine the sacred values of Islam:

It is said that Mohammed stopped at the knoll on his legendary overnight journey from Mecca to Jerusalem and back, riding his mythical horse, el-Buraq, which had the face of a woman, the tail of a peacock, and could gallop in a single stride as far as the eye could see. Mohammed, any villager will tell you, leaped from the knoll at Tabah and landed in Jerusalem. Mohammed was followed to this place by the armies that swept out of the desert under the banner of Islam to evict the Christians from the Holy Land.

(The Haj 26)

It goes without saying that Uris unveils his hidden hatred of Islam through giving fallacious information about important events of Islamic culture. For example, he says," Mohamed came to Tabah, followed by the armies that swept out the desert under the banner of Islam to evict the Christians from the holy land." (The Haj 15) He deviates from the history of Arab region, because it is historically documented that Omar lbn Al-Khattab is the Muslim leader who gave orders to the Muslim army to conquer Palestine not Prophet Mohamed. Omar Ibn Al-Khattab held a treaty with Christians when he entered Jerusalem by giving them safety and freedom to practice their rituals:

In the name of God, the Merciful, the Compassionate. This is the assurance of safety which the servant of God, Umar, the Commander of the Faithful, has given to the people of Jerusalem. He has given them an assurance of safety for themselves, for their property, their churches, their crosses, the sick and healthy of the city and for all the rituals which belong to their religion. (qtd. in Orakhelashvili 339) 
In general, Uris's writings concentrate on major effective historical and social events in the Middle East. He scrutinizes Jewish and Arab life from his own perspective, using a Zionist voice. By doing so, he gives priority to Zionist characters and assigns Arabs shadowy positions. Giving one side of the story, thus, creates a biased atmosphere that questions the credibility of the author himself and negatively affects his readers. Uris fails to look objectively at the two worlds, the Arab and the Jewish, showing Arabs as the primary "enemies" of Jews.

Though Uris handles many fictional and factual characters in the novels, he disregards creating a leading character that can represent dramatic action, something which creates an incomplete atmosphere of narration. Most incidents and events of the novels can be sensed rather than seen. This is an unsophisticated narrative device of employing a Zionist voice that the reader can easily identify. Presumably, this device may satisfy the contemporary Zionist taste, not the Arab one. For example, Uris uses Gideon of The Haj and Ari of Exodus as superheroes not as normal characters that can be assimilated to average man. These characters cannot create a climax, but they can offer readers a dream-like atmosphere. As a result, Uris's characters can be labeled as supernatural creatures.

Though specialized in historical fiction, Uris is highly criticized for preferring characters to events. He is not much interested in structure or even using proper words for certain characters; therefore, his dialogue sometimes may seem wooden and vague. On many occasions in Exodus and The Haj, the language ascribed to certain characters does not reflect their personalities. Therefore, a reader may not notice the main aspects of Uris's characters. Though considered an excellent storyteller, Uris is not highly regarded by critics 
for his weakness as a professional writer, according to Fischel, "Both Uris's immense popular appeal and what they perceived as flaws in regard to traditional literary standards, asserting that, in short, Uris remains a reader's delight and a critic's nightmare." (2) Sometimes concentrating on one component of the main formula of a novel can affect the credibility of major incidents and events. As a best seller novelist, Uris should have concentrated more on the primary components of his novels, i.e. the main plot, style and choice of words. However, he only cares about portraying his characters, an attitude which creates a vague style and interconnected ideas. Many critics have expressed their annoyance at his style, choice of words and expressions. Nevertheless, Uris jeopardizes his reputation as a best-seller writer for the sake of creating pro-Jewish novels; according to Decter:

Mr. Uris writes as he writes; whatever the subject, his
sensibility remains what it is. But for his readers,
particularly his Jewish readers, he has created the
possibility of seeing Jews not as the troublesome and
incomprehensible heroes that decent social conscience has
always demanded but as the kind of heroes that middle-
class dream life has conditioned us all to make our most
immediate responses to. (119)

Moreover, the excessive description of landscapes is another technique that affects the main course of the novel. Uris describes Palestine as a "desert" that can be turned into paradise by the hands of Jews. On every occasion, he stresses the importance of the land of "milk and honey" through undercurrent technique to show that Islamic civilization has been built on the ruins of a Hebrew one. According to him, Arabs and Islamic civilization have shattered Christian antique relics in Palestine: 
Mark could see the twin minarets that spiraled over the skyline from the Turkish section of the old city. The minarets that belonged to St. Sophia's, that magnificent crusader cathedral turned into a Moslem mosque. As they drove along the wall they passed the enormous ramparts shaped like arrowheads. (Exodus 4)

It is important to point out that Exodus and The Haj are not fully historical novels that derive their events from the Middle East, as Uris claims. But, they are simply books full of fabricated images of a certain race. These two novels are samples of hundreds of antiArab books produced annually to deform the Arab culture and religion. Further, they are misleading Zionist attempts to keep American people ignorant about the nature of Zionism. Therefore, Uris as a Zionist writer intends to falsify the history of Arab struggle against Zionists by ignoring the pressure of the Israeli military occupation on Palestine. Instead of tracing the destructive effects of Zionism on Palestinians, he pursues his endeavor to undermine Arab history, religion, identity and culture.

Most writers of popular fiction, who used to attack Arabs, follow Uris's pattern of writing. The message behind their novels is that Arabs have no right whatsoever to struggle or defend their land, culture and religion. Any Arab who preserves his traditions and customs is regarded as "uncivilized" and does not deserve to live among "civilized Jews". Thus, Arab characters are generally presented without true feelings and motivations, and their discourses are unsuitable and unequal to Jewish ones. In their delineation, writers of historical fiction narrowly depict Arab characters and major historical events, an attitude which may create a false presentation of history.

By submitting his own fingerprint on historical fiction, Uris accomplishes the mission assigned to him by Jewish-American public relations. For him and other cultural Zionists, 
the establishment of a Jewish state can be first fulfilled by physical building and actual work. Yet, the continuation of this state shall be achieved through a unique cultural centre, supported by Jewish literary works. Cultures in general and historical fiction in particular constitute a hidden weapon, which can turn scales upside down. On this basis, Uris' images in Exodus and The Haj, serve the purpose of strengthening Israel's claims as "a civilized state" surrounded by "vicious enemies", who want to exterminate Jews. To confirm his claims, Uris tries to turn his blind eye to many historical events to justify his false image of Arabs and the history of the Arab-Israeli conflict.

In Exodus and The Haj, Uris's images aim to serve Jewish claims of establishing a peace-loving state surrounded by vicious enemies, who are willing to kill every Jew. Hence, excessive use of war machine against Arabs is acceptable to achieve the ultimate goals of the peaceful state. To Uris, Jewish violence is no more than a "self defense" strategy. Moreover, according to Uris, Jews aim to lead a civilized life; thus, Jews are presented as the holders of western modern values. Therefore, one can find many similarities between the civilized European man and the Jew in Palestine. To give a realistic atmosphere to his novels, explanatory remarks about Jewish contributions to Palestine are voiced through many Arab characters to give a grandeur effect to Jews and highlight the civilized mission of Jews on the lands of Palestine. 


\section{Primary Sources.}

Uris, Leon. The Haj. New York: Bantam Books, 1984. Exodus. New York: Doubleday, 1958.

\section{Secondary Sources.}

Decter, Medge. Popular Jews. Coward, McCann \& Geoghegan, 1971.

Fischel, Ack. The Holocaust and Its Religious Impact. Praeger, 2004. http://www.thefreelibrary.com/Remembering+Leon+Uris.-a0226362478.

Hawthorn, J. Studying The Novel. London: Hodder Arnold, 2005.

Khalidi, Rashidi. "The 2010 Edward Said Memorial Lecture." Transcript No.339,http://www.thejerusalemfund.org/ht/display/ContentDetails/i/16422, 2010.

Orakhelashvili, Alexander. Research Handbook on the Theory and History of International Law. Edward Elgar Publishing, 2011.

Reyniér, Jacque de. Popular Literature and Imperialism. Online. Internet. 15 September 2003. FTP Available. http://www.shu.ac.uk/schools/cs/teaching/jb2/pcn/" VI "top" Roth, Philip. "Some New Jewish Stereotypes." Reading Myself and Others. New York: Farrar, Straus and Giroux, 1975.

Silver, Mathew. Our Exodus: Leon Uris and the Americanization of Israel's Founding Story. Wayne State University Press, 2010.

Terry, Janice. Mistaken Identity: Arab Stereotypes in Popular Writing. Middle East Policy Council, 1985.

The Holy Qur'an. Translated by Muhammed Taqi-Din Al-Hilali "Al-Anbiaa': 107, King Fahd, Complex for printing, Madinah, K.S.A. 1404. 